\title{
General Adjustment Influence Factor of Malaysian Construction Expatriates Executives Abroad
}

\author{
Halmi Zainol ${ }^{1, a}$, Haryati Mohd Isa ${ }^{2}$, Kartina Alauddin² and Mohmad Mohd Derus ${ }^{2}$ \\ ${ }^{1}$ Town and Regional Planning Department, Faculty of Architecture, Planning and Surveying, Universiti Teknologi MARA, Seri Iskandar \\ Campus, 32610 Perak, Malaysia \\ ${ }^{2}$ Quantity Surveying Department, Faculty of Architecture, Planning and Surveying, Universiti Teknologi MARA, Seri Iskandar Campus, \\ 32610 Perak, Malaysia
}

\begin{abstract}
The success of Malaysian construction companies creates an opportunity to explore abroad. Past studies have shown that the difficulty of expatriates in adjusting to a new environment is the main aspect that leads to failure of assignments. The success in implementing an overseas assignment does not solely depend on an expatriate's technical expertise. The adjustment issues such as the interaction with the host nationals, and adaptability to the host country's culture also exert influence on the assignment. The research was conducted to identify the influence of executive expatriate general adjustment on assignment in host countries. The objective of the study was to identify adjustment influence factors relating to general adjustment abroad. Questionnaires were sent to Malaysian expatriate executives. Sixty four Malaysian expatriate executives from Malaysian construction companies overseas were involved in this study. The findings show interaction, social and living environment influences their adjustment during expatriation. Pre-departure training preparation aspects for expatriates is a good step before their departure to host countries.
\end{abstract}

\section{Introduction}

The present internationalization of the construction industry shows that Malaysian firms are getting more involved in construction projects abroad. The involvement of companies to secure projects overseas can strengthen the position of the company. However, to be successful, a company must ensure that individuals selected to work overseas must have the perseverance and must be ever ready to face challenges.

To a great extent, success of the companies depends on the employees assigned to the projects overseas. The efficiency of staff assigned abroad depends not only depends on their technical capabilities, knowledge, and creativity, but also on other non-technical matters that influence the staff in foreign countries. The control over these factors would enable the optimum use of employment for ensuring success of a company [1,2].

The ability of the expatriates to adjust to general aspects, jobs, and family influences their performance in their assignments $[3,4,5]$.The different environmental conditions in the host countries suggest the importance of expatriates of making adjustment so that they can enjoy their normal life. Not all staff sent overseas can adjust themselves to the situation overseas. Therefore, to face the new environmental condition in a foreign country, preparation and adjustment of an expatriate is imperative.

\footnotetext{
a Corresponding author: halmi461@perak.uitm.edu.my
}

Among the reasons for Malaysian construction companies getting involved in a foreign country is to secure market access in the host country, to increase their market share, to strengthen their networking and to gain experience [6]. The success of a Malaysian construction company to secure a highway project overseas worth RM17.5 billion has opened up opportunities to local Malaysian companies to invest in foreign construction projects [7]. This shows foreign recognition towards the capabilities of Malaysian construction companies. Such opportunities have become the foundation for Malaysian companies to implement foreign projects successfully, apart from increasing their contribution to the national economy. In this connection, the need for Malaysian expatriate to lead this kind of projects has become a priority.

\section{Problem Statement}

Malaysian multinational construction companies are getting projects in foreign countries such as in the Southeast Asian region, the Middle East, Asia, Africa and other countries $[8,9]$. Table 1 shows, up till December 2010 , altogether 96 projects with an estimated value of RM40,404.54 million were in operation in foreign countries. The projects were distributed in South Asia (32.3\%), Middle East (27.1\%), Asian (21\%), and the rest 
in other countries. According to [6], the fact that $79 \%$ of these companies intend to expand their operations overseas within five years is a positive development regarding the involvement of Malaysian multinational construction companies in foreign countries.

Table 1. Involvement of Malaysian Multinational Construction Companies in Foreign Countries

\begin{tabular}{|c|c|c|c|}
\hline Region & $\begin{array}{l}\text { No. of } \\
\text { project } \\
\quad \text { s }\end{array}$ & $\%$ & $\begin{array}{l}\text { Project } \\
\text { value } \\
\text { (RM } \\
\text { mil.) }\end{array}$ \\
\hline Asian & 21 & $9^{21 .}$ & $6,087.28$ \\
\hline $\begin{array}{l}\text { Middle } \\
\text { East }\end{array}$ & 26 & 27. & $16,378.80$ \\
\hline Africa & 6 & 6.2 & $7,033.40$ \\
\hline $\begin{array}{l}\text { South } \\
\text { Asia }\end{array}$ & 31 & $3^{32 .}$ & $8,257.52$ \\
\hline Others & 12 & $5^{12 .}$ & $2,647.54$ \\
\hline Total & 96 & 100 & $40,404.54$ \\
\hline
\end{tabular}

Note. Adapted from Zakaria, 2011

Among the problems faced by expatriates when in foreign countries are that they are unable to cope with the situation of being in a new environment and that they are unable to adjust themselves in performing their heavy responsibilities overseas [2], [10]. Therefore, the adjustment aspects of facing the situation in the host country should be taken into consideration by companies so that expatriates can have some expectations about the problems they will be facing overseas.

Initiatives have been taken by the Construction Industry Development Board (CIDB) to encourage local contractors to participate in construction projects abroad. The government through DICB has produced a directory of construction companies involved in construction projects abroad. In addition, the government has published the Malaysian Builders Go Global to establish a communication network for the construction industry. With these facilities, Malaysian construction companies can have direct communications with international markets and expand the construction industry in Malaysia, at the same time contributing towards the Malaysian economy. The involvement of the Malaysian multinational construction companies abroad was with their own initiatives [11]. Therefore, when operating abroad, companies have to give priority to the requirements of their staff to facilitate them in performing their tasks.

The general adjustment experienced by executive expatriates affects their work satisfaction and motivates them in performing their assignments [12]. Expatriates not only have to perform their assigned responsibilities well, but also have to face environment changes that require psychological strength to adjust to. Therefore, it is important to understand the changes they have to face when abroad.

This study focuses on ways to solve the problems faced by expatriates in their host countries. The question that needs to be answered in this study is that whether there are any non-technical aspects of general adjustment faced by expatriates of Malaysian multinational construction companies in their host countries, and to what extent these non-technical factors contribute to the adjustment factors.

\section{Literature Review}

General adjustment involved changes in lifestyle, social status, and comfort faced in the new situation [13, 14]. Life, for every individual is an adaptation process to the existing situation and creating good communication with the environment. Adjustment to new environment condition affects the psychology of the expatriates in the host country [1], [15]. If people are affected psychologically such as if they are feeling discomfort, sadness, and worrisome, when performing their duties, it is a sign that they are unable to adjust to the new situation.

Based on the U-curve adjustment theory, expatriates experience psychological changes after being in a host country. [16], maintained that adjustment is obtained when they have accepted and understood the changes that exist in the host country. At the early stage, the expatriates would not feel the difficulties because they are in a stage of "fantasy". However, after a while being in the host country, differences start to surface as in location of their settlement and culture shock. Nevertheless, the expatriates have to understand and accept these differences that occur. Previous study found that Japanese expatriates require at least four years making adjustment [17]. Expatriates from monoculture countries such as Japan find it difficult to adjust to situation in other countries that have different cultures [18].

General adjustments with regard to food, shopping and banking have also been studied. According to [18], expatriates would face new things, especially food when they are in their host country. Prior exposures to food in the country where the expatriates would be staying will help them get prepared for the changes that they will be facing. Some expatriates often go to work in several countries, and yet they still need this kind of adjustment for their daily comfort $[19,20]$. This view is supported by [21] when they agreed that adjustment to food is more crucial compared with adjustment to health facilities, standard of living, and entertainment. With regard to shopping, it was found that shopping is a required daily spending activity for people [20]. Moreover, there are also differences in the way people do shopping in the home country as compared with the host country. [22] observed that expatriates need to adjust to shopping because in some host countries bargaining is practiced while in their home country bargaining may not be practised.

According to [23], the difficulties faced by expatriates to adjust to the living standard in the host country would lead to other difficulties. Some expatriates who live in a host country tend to compare the situation there with that in their home country where it is more comfortable. [20] agreed with this view. They said that one of the reasons staff refuse the offer to work abroad is that the living 
standard in the host country is different from that of the home country. If the living standard in the host country is higher than that of their home country, it would be difficult for the expatriates to adapt to the situation in the host country [24]. Findings by [25, 26] showed that adjustment to living standards is positively correlated with adjustment of expatriates in their host countries. This shows that adjustment to living standards influences adjustment of expatriates in their host countries. [26, 27], are among researchers, who has taken into consideration the living standards adjustment of expatriates.

The interaction with host country citizens is related closely with the activity of socializing with the local citizens of the host country. This refers to how comfortable the expatriates interact with local citizens when they are performing their tasks and when outside their tasks [23], [26], [28-30]. Previous expatriate research has shown that one main problem of adjustment of expatriates is their difficulty to interact with local citizens during their appointment in the host country [23]. [31] also found same problem faced by expatriates. According to [32], because expatriates face difficulties to interact, their adjustment would take a longer time, which in turn affects their job performance. In addition, expatriates need to interact with the environment to enable them to take positive actions to facilitate their adaptations with local citizens [30], [35,36].

Adaptation to the culture of the host country is an adjustment to the cultural practice and the customs of the local citizens in the host country [33]. Individuals who can accept the differences in the host country will face less adjustment problems. According to [34], it is difficult for individuals to adjust to a situation with a different socio-economy and society. In addition, [35], [37] believed that language is closely related to culture.The language is the foundation of culture for a country [2]. By having good communication with the local citizens, one shows that he or she is trying to understand and adapt to the local culture. This will facilitate cultural adjustment. Expatriates who have less interactions and making less cultural adaptation to the culture of the host country will require a longer time to make adjustment [26].

\section{Methodology}

This study uses the questionnaire to collect data. The population is based on the list of Malaysian construction companies operating in foreign countries, which is obtained from the Construction Industries Development Board (CIDB). Questionnaires were distributed to Malaysian expatriates assigned to their various host countries. However, the questionnaires were sent, attached with a covering letter, through e-mails to the human resource managers to be forwarded to their executives working abroad. Three follow-up actions were taken to obtain their responses [36]. Finally, 64 questionnaires were returned by the respondents. Data obtained were analysed using Statistical Package for the Social Science software (SPSS). Data analysis was performed using the quantitative approach as the data obtained were measured using nominal data.
Reliability test were performed using the Cronbach's alpha for determining the reliability of the items tested [38]. Factor analysis procedures were performed based on the interpretation of the research question and findings from statistical analysis [27], [39]. The measurement scale made use of 5-point Likert scale with $1=N o$ adjustment at all to $5=$ Full adjustment $[40,41]$. A mean score less than 2.5 represents no adjustment [6], [42].

\section{Results and Discussion}

The general dimension consists of 13 items, which include living condition, housing condition, religious practices, and types of local food, shopping, banking, and living standards. Reliability tests performed on the general dimension obtained the value of $\alpha=.89$. The items with value of Cronbach's $\alpha$ greater than .7 were selected because they have acceptable reliability values.

Using the Principal Component Analysis (PCA), factor analyses were performed on the 13 items. One item, that is, food suitability was dropped for having communalities value less than .5. The factor analysis procedure was repeated and returned a Kaiser-MeyerOlkin (KMO) value of .79 (> .6). The Barlett's test of Sphericity was significant at $p=.00(p<.01)$, and communalities values for all items were greater than .5 , as shown in Table 2. The largest eigen value was 5.49 for the first factor, followed by 1.52 for the second factor, and 1.12 for the third factor. The first factor obtained the largest eigenvalue because it gave the largest contribution to the changes in the total variance of the changes in the variables [43]. The results from the factor analyses have grouped three factors which together explained $67.74 \%$ of the total variance where the first factor explained $45.76 \%$, followed the second factor, which explained $12.65 \%$, and the third factor, which explained $9.33 \%$.

Table 2, Factor Analysis for General Adjustment

\begin{tabular}{|c|c|c|c|}
\hline Item & FL & CA & EV \\
\hline $\begin{array}{l}\text { Factor } 1 \text { Interaction } \\
\text { Adjustment } \\
\text { Socializing with local }\end{array}$ & .76 & & \\
\hline $\begin{array}{l}\text { Interaction with host } \\
\text { nationals }\end{array}$ & .88 & .78 & 5.49 \\
\hline Communication & .87 & & \\
\hline Culture adaptation & .75 & & \\
\hline $\begin{array}{l}\text { Factor 2 } \\
\text { adjustment }\end{array}$ & 67 & & \\
\hline Banking & .72 & & \\
\hline Cost of living & .67 & .78 & 1.52 \\
\hline Entertainment & .60 & & \\
\hline Healthcare & .64 & & \\
\hline $\begin{array}{l}\text { Factor 2 } \quad \text { Living } \\
\text { environment } \\
\text { Living condition }\end{array}$ & .76 & & \\
\hline Housing condition & .84 & .89 & 1.12 \\
\hline Religious practice & .75 & & \\
\hline $\begin{array}{l}\text { KMO Measure of } \\
\text { Sampling Adequacy }\end{array}$ & .79 & & \\
\hline
\end{tabular}


\begin{tabular}{l|c} 
Barlett's test of Sphericity & $398.39 *$ \\
Anti-Image Correlation & $.67-.93$ \\
Matrix (MSA) & \\
Total Variance & $67.74 \%$
\end{tabular}

Note: $\mathrm{FL}=$ Factor Loading, $\mathrm{CA}=$ Cronbach's

Alpha, EV= Eigen Value.

$p<.01 *$. Cronbach's alpha coefficients with values less than 0.7 were deleted.

The three factors were called interaction adjustment, general adjustment, and living environment. The interaction adjustment factor comprised items such as socializing with the local society, interaction with local citizens, and adapting to the culture of the host country. The second factor was the social adjustment factor, which include banking, shopping, living standards, recreational and entertainment facilities, and health facilities. The third factor was the living environment, which included living condition, housing condition, and religious practices. After the factors of the items have been identified, reliability tests were performed to determine the reliability of each factor. The Cronbach's alpha reliability test for the general dimension obtained an alpha value for social interaction adjustment factor, $\alpha=$ .78 and environment atmosphere factor, $\alpha=.89$ Therefore, the reliability of both the factors were acceptable.

The results showed that out the 13 items tested, 12 of them were chosen, showing that those items have an influence on the expatriates' general adjustment in facing the new environment in their host countries. The item on food adjustment was dropped. This result contradicted the results of previous research done by [23], [21]. These authors have included this item on food adjustment. Nevertheless, in the present research, the item was dropped because it did not contribute to factor variance proportion [44, 45]. From the 12 items of general adjustment, three factors were extracted and named interaction adjustment, social adjustment and living adjustment in accordance with the group of items in the factor.

Four items were grouped under interaction adjustment factor. The items were socializing with local society, interacting with local citizens, communication, and adaptation with culture of the host country. These three items were grouped in accordance with [26], [46]. However, [23] did not include the communication item in his research. This shows that the item socializing with local society, interacting with local citizens, communicating and adapting to the culture of the host country is an important aspect which need to be taken into account in expatriates' general adjustment in their host countries.

With regard to general adjustment, five items were grouped under this factor. This was based on the factor analysis procedure performed. The items extracted were shopping, banking, living standards, recreational and entertainment facilities, and health facilities. [23] has outlined three items that contribute to general adjustment, namely shopping, banking and living standards. However, studies by $[46,47]$ have included recreational and entertainment facilities and health facilities under general adjustment. It seems that there is a difference of opinion between the present research and previous research by [23], [46], who did not include the aspect of health facilities. The combination of all these items grouped under one factor demonstrates the importance of these items to general adjustment. This is in line with previous analysis and literatures which stressed on the comfort of expatriates in adjusting to the living environment in their host countries [36].

Three items were clustered under the living environment factor for general dimension, namely living condition, housing condition, and religious practices. The item living condition and housing condition used by [21] $[46,47-48]$ are adjustment items that affect adjustment to environment condition. The item religious practices have been considered by $[49,50]$ as having an influence on expatriates' adjustment. However, the present study contradicted this notion.

\section{Conclusion}

The study found that three factors, namely interaction adjustment, social adjustment, and living environment contribute to non-technical adjustment in the general dimension. The interaction adjustment aspect, namely communication, cultural adaptation, and socializing with local society need to be considered because expatriates are unable to adjust with those aspects in their host countries.

With regard to general adjustment, those elements associated with health facilities, banking, and recreational and entertainment need to be given serious attention. However, expatriates do not face any problems and they can adjust to the conditions and the living condition. Housing provided by their companies also affects this outcome. Therefore, three factors have been identified, namely interaction adjustment, general adjustment, and living environment. These factors have provided the answer to the fulfilment of the first objective of the study. The first objective is about the non-technical adjustment challenges faced by Malaysian expatriates in the construction industry, in their host countries.

The research findings have identified several factors that affect the general adjustment of Malaysian expatriates in the Malaysian construction industry. Companies and individuals sent abroad need to realise that there are also non-technical factors that would cause the successful implementation of projects abroad. The interaction adjustment and general adjustment provide the largest contribution to expatriates' adjustment in their host countries. Other factors such as social relationship with local society, adaptation to the culture of the host country, and communication are among aspects that should be given more attention by companies so that expatriate executives can make adjustments to a new environment abroad. This study suggests that future research need to focus on family adjustment because this factor also influences expatriate adjustment. In addition, future studies should also pay more attention to 
qualitative approach in their studies so that the real issues faced by expatriates can be brought to light.

\section{References}

1. A. W. Andreason, K. D. Kinneer, Repatriation Adjustment Problems and the Successful Reintegration of Expatriates and Their Families. J. of Behav. and Appl. Manage., 6, 109-126 (2005).

2. N. Yang, A Cross-cultural Contextual Model of WorkFamily Interfaces in Managing International Assignments. J. of Int. Bus. Res., 6, 1-10 (2007).

3. B. A. Anderson, Expatriate Management : An Australia Tri-Sector Comparative Study. Thunderbird Int. Bus. Rev., 4, 33 - 52 (2001).

4. J. P. Katz, D. M. Seiffer, It's a Different World out There : Planning of Expatriate Success through Selection, Pre Departure.... Hum. Resour. Planning, 19, 32-49 (1996.)

5. Y. Paik, B. Segaud, C. Malinowski, How to Improve Repatriation Management - Are motivations and expectations congruent between the company and expatriates. Int. J. of Manpower, 23, 635-648 (2002).

6. A.-R. Abdul-Aziz, S. S. Wong, Competitive Assets of Malaysian Int. Contractors. J. Financ. Manage. Prop. Constr., 15, 176-189 (2010)

7. S. A. Mansor, Perhimpunan bulanan bersama warga KKR. Jabatan Kerja Raya, unpublished, Kuala Lumpur (2011).

8. CIDB Malaysian Contractors' Achievements in the Global Market, Construction Industry Development Board, Kuala Lumpur (2009).

9. M. Z. Zakaria, Entry Strategies for Malaysian Construction Related Companies Going Abroad. Paper presented on National Seminar in Built Environment (NSiBE) Kuala Lumpur (2011).

10. A. A. M. Osman-Gani, S. H. Akmal, Repatriation Readjustment of International Managers; An Empirical Analysis of HRD Interventions. Career Develop. Int., 13, 456-475 (2008).

11. A.-R. Abdul-Aziz, S. S. Wong, Exploring the Internationalization of Malaysian Contractors: The International Entrepreneurship Dimension. Constr. Manage. and Econ., 28, 51-61 (2010)

12. R. Takeuchi, P. L. David, V. M. Sophia, Y. Seokhwa, Nonlinear influences of stressors on general adjustment: the case of Japanese expatriates and their spouses. J. of Int. Bus. Stud., 38, 928-943 (2007).

13. J. S. Black, M. Mendenhall, G. Oddou, Towards a Comprehensive Model of International Adjustment : An Integration of Multiple Theoretical Perspectives. Acad. of Manage. J., 16, 2, 291-317 (1991)

14. H.-K. Chi, C.-Y. Chiou, The Work Adjustment of Taiwanese Expatriates. The Bus. Rev., 8, 267-272 (2007).

15. J. Selmer, A. S. M. Leung, Symptom and Problem Focused Coping Strategies of Business Women Expatriates and Their Socio-cultural Adjustment in
Hong Kong. Women In Manage. Rev., 22, 588-605 (2007).

16. G. Pires, J. Stanton, S. Ostenfeld, Improving Expatriate Adjustments and Effectiveness in Ethnically Diverse Countries: Marketing Insights. Cross Cult. Manage. : An Int. J., 13, 156-170 (2006).

17. Y. Yamazaki, A fit between skills and demands among Japanese expatriates in USA. Manage. Int. Rev., 50, 81-108 (2010).

18. A. Webb, P. C. Wright, The Expatriate Experience: Implications for Career Success. Career Develop. Int., 1, 38-44 (1996).

19. H. B. Gregersen, J. S. Black, Antecedents to Commitment to a Parent Company and a Foreign Operation. Acad. of Manage. J., 35, 65-90 (1992).

20. K. Hutchings, S. W. Ratnasari, Cross-cultural Nonwork Transition Stresses: Domestic Transferees in Indonesia. Cross Cult. Manage. : An Int. J., 13, 114-131 (2006).

21. J. McGingley, Expatriate Adjustment Within A Social Context : Examination of Sample in Russia. J. of Soc., Evolutionary and Cult. Psychology, 2, 56-68 (2008).

22. P. Caligiuri, M. Lazarova, S. Zehetbauer, Top Managers' National Diversity and Boundary Spanning : Attitudinal Indicator of a Firm's Internationalization. J. of Manage. Psychology, 23, 848-859 (2004).

23. J. S. Black, Work Role Transitions : A Study of American Expatriate Managers in Japan. J. of Int. Bus. Stud., 19, 277 - 294 (1988),

24. D. G. Collings, H. Scullion, M. J. Morley, Changing Patterns of Global Staffing in the Multinational Enterprise: Challenges to the Conventional Expatriate Assignment and Emerging Alternatives. J. of World Bus., 42, 198-213 (2007).

25. J. S. Black, H. B. Gregersen, The Right Way to Manage Expats. Harvard Bus. Rev., 77, 52-63 (1999).

26. T.-J. Huang, Shu-Cheng \& J. J. Lawler, The Relationship Between Expatriates' Personality Traits and Their Adjustment to International Assignments. The Int. J. of Hum. Resour. Manage., 16, 1656-1670 (2005).

27. A. Fish, Assisting Cross-border Manager Adjustment: Psycho-cultural and Socio-cultural Interventions. Personnel Rev., 24, 225-245 (2005).

28. P. Bhaskar-Shrinivas, D. Harisson, M. A. Shaffer, D. M. Luk, Input-Based and Time-Based Models of International Adjustment: Meta-Analytic Evidence and Theoretical Extensions. Acad. of Manage. J., 48, 257-281 (2005).

29. H.-F. Chen, The Relationships of Organizational Justice, Social Exchange, Psychological Contract, and Expatriate Adjustment : An Example of Taiwanese Business Expatriates. The Int. J. of Hum. Resour. Manage., 21, 1090-1107 (2010).

30. M. A. Shaffer, D. A. Harrison, H. Gregersen, J. S. Black, L. A. Ferzandi, You Can Take It With You: Individual Differences and Expatriate Effectiveness. J. Of Appl. Psychology, 91, 109-125 (2006). 
31. V. Suutari, K. Riusala, Operating in 'Economics in Transition' - Adjustment and Management Issues Faced by Finnish Expatriate Managers in CEE. 87107 (2000).

32. J. Selmer, which Is Easier, Adjusting to a Similar or to a Dissimilar Culture. Cross Cult. Manage., 7, 185-201. (2007)

33. S. J. Shin, F. P. Morgeson, M. A. Campion, What Do You Depends On Where You Are : Understanding How Domestic and Expatriate Work Requirements Depend Upon The Cultural Context. J. of Int. Bus. Stud., 38, 1, 64-84 (2007).

34. K. G. Lewis, Breakdown - A Psychology Contract for Expatriates. European Bus. Rev., 97, 6 (1997).

35. J. S. Black, M. E. Mendenhall, The U-Curve Adjustment Hypothesis Revisited : A Review and Theoretical Framework. J. of Int. Bus. Stud., 22, 225-247 (1991).

36. J. P. Shay, S. Baack, An Empirical Investigation of the Relationships Between Modes and Degree of Expatriate Adjustment and Multiple Measures of Performance. Int. J. of Cross Cult. Manage., 6, 275 294 (2006).

37. S. L. O'Sullivan, International performance appraisals: A review of the literature \& agenda for future research. Journal of American Academy of Business, Cambridge, 14, 171-180 (2009).

38. S. J. Coakes, L. Steed, P. Dzidic, SPSS version 13.0 for Windows Analysis Without Anguish. Sydney: John Wiley \& Sons Australia (2006).

39. T. Roshana, E.M. Ahnuar, Analysis of Efficiency and Effectiveness Measures of Construction Project Success in Malaysia. International Conference in Built Environment - iCiBE 2006. Kuala Lumpur 13-15 Jun (2006).

40. E. Babbie, The Practise of Social Research (12th Edition ed.). Wadsworth: Nelson Education Ltd. (2010).

41. W. L. Neuman, Social Research Methods Qualitative and Quantitative Approaches (6th ed.). Boston: Pearson Education Inc. (2006).

42. F. E. Hurme, Competencies for rural nursing practise. Louisiana State University, Louisiana (2007).

43. C. Y. Piaw, Statistik Penyelidikan Lanjutan : Ujian Regresi, Analisis Faktor dan Analisis Sem-Buku 5. Kuala Lumpur: Mc. Graw Hill (Malaysia) Sdn. Bhd. (2009)

44. A. Field, Discovering Statistics Using SPSS (Third ed.). London: SAGE Publications Ltd. (2009)

45. C. K. D. Lorio, Measurement in Health Behaviour Methods For Research and Evaluation. San Francisco: Jossey-Bass (2005).

46. L.-Y. Lee, D. V. Vorst, The Influence of Social Capital and Social Support on Expatriates' Cultural Adjustment: An Empirical Validation in Taiwan. Int. J. of Manage., 27, 628-649 (2010).

46. M. d. G. H. O. d. Pamich, Cross-Cultural Adjustment and The Expatriate Spouse : A Case Study. Capella University, USA (2007).

47. S. M. Toh, Host Country Nationals to the Rescue: A Social Categorization Approach to Expatriate
Adjustment. Unpublished thesis. Texas A\&M University, Texas (2003).

48. M. Bastida, M.T. Cancelo, Expatriate Performance and Permanence: Analysis By Gender of 124 Spanish Managers. Appl. Econ. and Int. Devt., 14, 51-64 (2014).

49. M. F. Tucker, R. Bonial, K. Lahti, The Definition, Measurement and Prediction of Intercultural Adjustment and Job Performance Among Corporate Expatriates. Int. J. of InterCult. Relat., 28, 221-251 (2004).

50. A. H. M. Tahir, M. Ismail, Cross-Cultural Challenges and Adjustments of Expatriates: A Case Study in Malaysia. Turkish J. of Int. Relat., 6, 72-99 (2007). 